\title{
A Meta-Analysis of the Analgesic Efficacy of Single-Doses of Ibuprofen Compared to Traditional Non-Opioid Analgesics Following Third Molar Surgery
}

\author{
Lorenzo Franco-de la Torre ${ }^{1}$, Norma Patricia Figueroa-Fernández ${ }^{2}$, Diana Laura Franco-González ${ }^{1}$, \\ Ángel Josabad Alonso-Castro ${ }^{3}{ }^{\mathbb{D}}$, Federico Rivera-Luna ${ }^{2}$ and Mario Alberto Isiordia-Espinoza $1, * \mathbb{B}$
}

1 Instituto de Investigación en Ciencias Médicas, Departamento de Clínicas, División de Ciencias Biomédicas, Centro Universitario de los Altos, Universidad de Guadalajara, Tepatitlán de Morelos 47620, Mexico; lorfran8888@hotmail.com (L.F.-d.1.T.); diana.franco5288@alumnos.udg.mx (D.L.F.-G.)

2 Departamento de Cirugía Oral y Maxilofacial, Facultad de Odontología, Universidad Autónoma de Baja California, Campus Mexicali 21040, Mexico; nfigueroa@uabc.edu.mx (N.P.F.-F.); rivera_103@hotmail.com (F.R.-L.)

3 Departamento de Farmacia, División de Ciencias Naturales y Exactas, Universidad de Guanajuato, Guanajuato 36250, Mexico; angeljosabad@hotmail.com

check for updates

Citation: Franco-de la Torre, L.; Figueroa-Fernández, N.P.;

Franco-González, D.L.;

Alonso-Castro, Á.J.; Rivera-Luna, F.; Isiordia-Espinoza, M.A. A Meta-Analysis of the Analgesic Efficacy of Single-Doses of Ibuprofen Compared to Traditional Non-Opioid Analgesics Following Third Molar Surgery. Pharmaceuticals 2021, 14, 360. https://doi.org/10.3390/ph14040360

\section{Academic Editors: Jean}

Jacques Vanden Eynde and

Félix Carvalho

Received: 28 March 2021

Accepted: 8 April 2021

Published: 14 April 2021

Publisher's Note: MDPI stays neutral with regard to jurisdictional claims in published maps and institutional affiliations.

Copyright: (c) 2021 by the authors. Licensee MDPI, Basel, Switzerland. This article is an open access article distributed under the terms and conditions of the Creative Commons Attribution (CC BY) license (https:/ / creativecommons.org/licenses/by/ $4.0 /)$.
* Correspondence: mario.isiordia162@yahoo.com; Tel.: +52-378-119-5786

\begin{abstract}
The purpose of this systematic review was to determine the analgesic efficacy and adverse effects of ibuprofen in comparison with other traditional non-opioid analgesics after third molar surgery. A total of 17 full texts were identified in PubMed and assessed using the Cochrane Collaboration's risk of bias tool by two independent researchers. The sum of pain intensity differences, total pain relief, the overall evaluation, the number of patients requiring rescue analgesics, and adverse effects were collected. Data were analyzed using the Review Manager Software 5.3. for Windows. A total of 15 articles met the criteria. The qualitative and quantitative analysis showed that ibuprofen is more effective to relieve post-operative dental pain than acetaminophen, meclofenamate, aceclofenac, bromfenac, and aspirin. Moreover, ibuprofen and traditional non-steroidal anti-inflammatory drugs have a similar safety profile. In conclusion, ibuprofen $400 \mathrm{mg}$ appears to have good analgesic efficacy and a safety profile similar to other traditional non-steroidal anti-inflammatory drugs after third molar surgery.
\end{abstract}

Keywords: ibuprofen; non-steroidal anti-inflammatory drugs; dental pain; adverse effects; third molar surgery

\section{Introduction}

The most common signs and symptoms after lower third molar extraction are postsurgical pain, facial swelling, and trismus [1-4]. These complications are closely related to soft tissue trauma and osteotomy during the surgical procedure [4,5]. The most intense postoperative pain occurs during the second and sixth hours after the extraction of the third molar, and some episodes can even occur during the next seven days [6,7]. Swelling and trismus reach their critical point between the second and third day and disappear approximately 1 week after surgery [8,9].

Non-steroidal anti-inflammatory drugs (NSAIDs) are the first option to control complications in oral surgery [10]. Particularly, ibuprofen is one of the most used drugs by general dentists and specialists worldwide for the control of inflammatory complications after third molar removal [11,12]. Besides, other NSAIDs are also broadly used for this purpose (e.g., diclofenac and paracetamol) [13-15]. This kind of drug induces its therapeutic and adverse effects by the inhibition of the cyclooxygenase enzyme [10-15].

Ibuprofen is widely used for pain management following third molar surgery [11,12]; however, there is not a practical guide to help the clinician decide whether to use this 
drug or another one that is available [11,12]. We found only one meta-analysis comparing ibuprofen with another drug. That study demonstrated that ibuprofen is more effective to relieve pain compared to acetaminophen in third molar removal [15]. Nonetheless, there is not a qualitative review of the analgesic efficacy of ibuprofen in comparison with other analgesics (different from acetaminophen) nor a quantitative assessment integrating the data to make a decision about which analgesic to use after third molar surgery. For that reason, the purpose of this systematic review was to determine the analgesic efficacy and adverse effects of ibuprofen in comparison with other traditional non-opioid analgesics following wisdom teeth removal.

\section{Material and Methods}

\subsection{Study Registration}

This systematic review (and meta-analysis) was registered on 18 December 2020, in the National Institute of Health Research from the University of York, United Kingdom (PROSPERO ID: CRD42021227135).

\subsection{Selection Criteria}

The inclusion criteria were as follows: Clinical trials comparing single-dose of ibuprofen versus non-opioid analgesics in lower wisdom teeth extraction using parallel or crossover design, including patients of both sexes and over 15 years old, reporting the effect of ibuprofen alone, and articles in English or Spanish. A loss to follow-up of more than $20 \%$ of those entered was the only exclusion criteria.

\subsection{Article Digital Searching}

The PubMed database browser was used to detect scientific articles that compared single-doses of ibuprofen with non-opioid analgesics. Two information filters from this browser were used: Type of article-selecting the boxes: clinical trial-and randomized controlled trial—and language-employing the boxes: English and Spanish. All articles found without date restriction until 31 December 2020, were included. The keywords used were the following: "Ibuprofen"; "Non-steroidal anti-inflammatory drugs"; "Diclofenac"; "Ketorolac"; Meloxicam"; "Piroxicam"; "Acetaminophen"; "Ketoprofen"; "Metamizole"; "Indomethacin"; "Naproxen"; "Third molar surgery"; "Oral surgery"; "Maxillofacial surgery".

\subsection{Quality Assessment}

The evaluation of bias was performed with the Cochrane Collaboration's risk of bias tool [16-18]. Studies rated low-risk (green color circle) or medium-risk (yellow color circle) of bias according to the summary figure were designated of high quality. Two researchers did the full-text evaluations and the differences were resolved with the participation of a third researcher $[19,20]$.

\subsection{Data Collection}

The primary results were as follows: Sum of pain intensity differences (SPID) at 2 and $6 \mathrm{~h}$ after surgery, total pain relief (TOTPAR or TOPAR) at 2, 4, 6, and $8 \mathrm{~h}$ following surgery, and overall evaluation (number of patients reporting a good, very good, and excellent effect). Moreover, the secondary outcomes were the number of patients requiring rescue analgesics within the first 24 post-surgical hours and adverse effects. When a clinical trial had two or more ibuprofen groups or when the active controls were several NSAIDs, the data were summed and evaluated in a single group (e.g., for the evaluation of adverse effects in the Forbes et al., 1991 study, there were two ibuprofen groups (200 and $400 \mathrm{mg}$ ) and two meclofenamate groups (50 and $100 \mathrm{mg}$ )) [21]. On the other hand, the percentages and proportions were converted to absolute numbers [21]. 


\subsection{Statistical Analysis}

The Review Manager Software 5.3. for Windows was used to carry out the pooled data analysis. The SPID and TOTPAR were evaluated using the inverse variance statistical method and means difference. The overall evaluation, the number of patients requiring rescue analgesics, and the adverse effects were assessed with the Mantel-Haenszel test and Odd Ratio (OR). The I2 test was interpreted according to Higgins and Green, 2011 [18,22]. A $p$-value $\leq 0.05$ was considered significant.

\section{Results}

3.1. Digital Search and Assessment of Bias

A total of 1281 articles were identified in PubMed, of which 17 were fully evaluated with the Cochrane Collaboration's risk of bias tool and, finally, only 15 met the requirements of our study [23-37] (Figure 1).

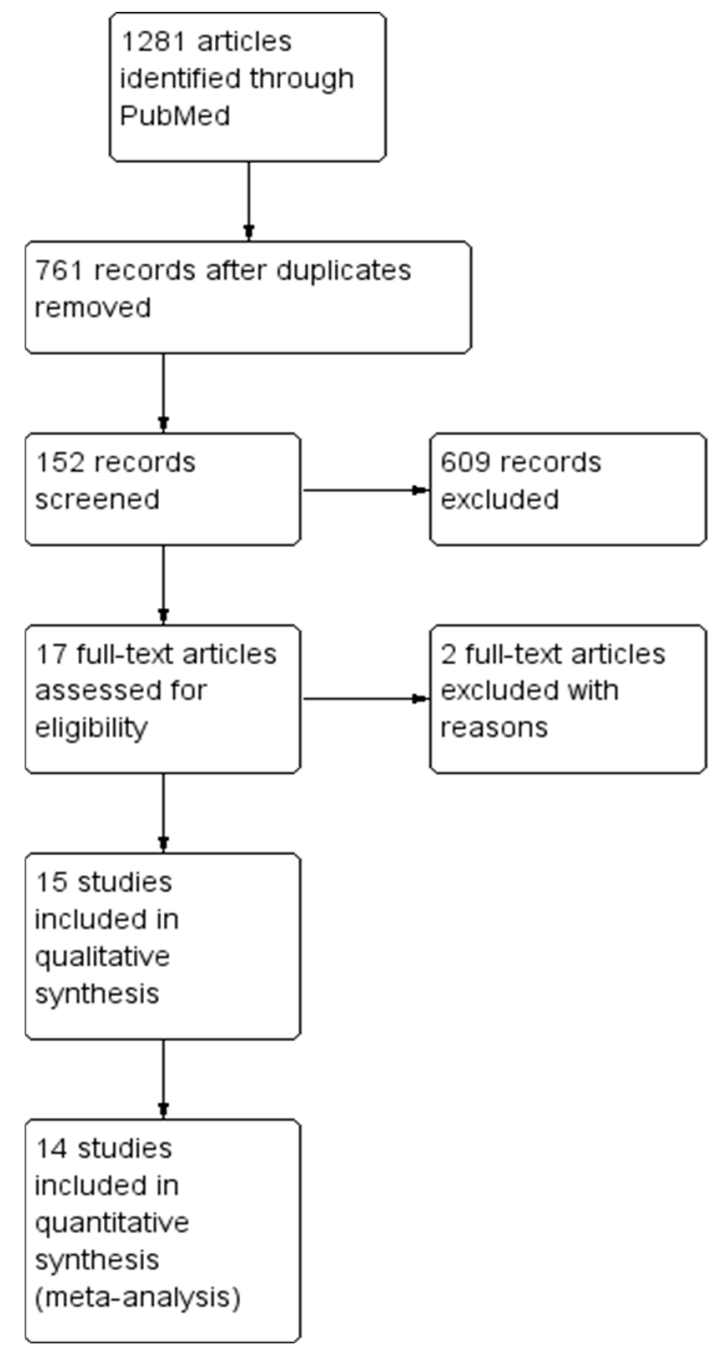

Figure 1. Study flow diagram.

\subsection{Qualitative Evaluation}

The assessment was done with 15 articles. Six clinical studies were in favor of ibuprofen, two reports presented similar analgesic effects, three assays showed no conclusions about the analgesic efficacy of ibuprofen, and four clinical trials informed a result against this drug [23-37] (Figure 2; Table S1). 
Random sequence generation (selection bias)

Allocation concealment (selection bias)
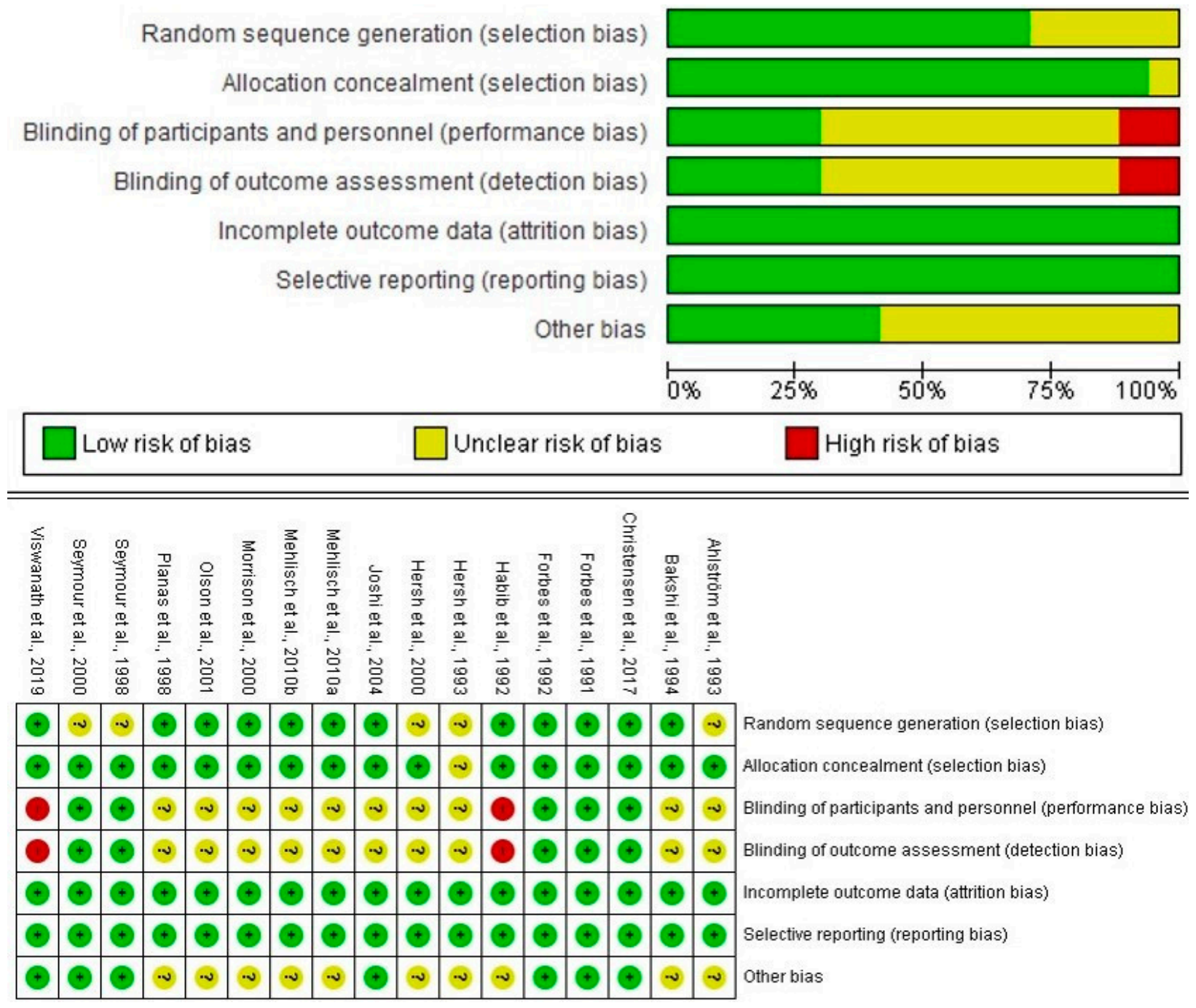

Figure 2. Evaluation of bias of the full-text articles.

\subsection{Analgesic Efficacy}

The quantitative analysis of the SPID showed that ibuprofen was superior to acetaminophen at 2 and $6 \mathrm{~h}$ after surgery. Furthermore, similar scores of the SPID were observed for ibuprofen and ketoprofen $2 \mathrm{~h}$ following surgery. However, at 6 post-surgical hours, ibuprofen had lower pain scores than ketoprofen (Table S2).

The TOTPAR meta-analysis confirmed these findings (Table S3). In addition, a lower dose of ibuprofen was inferior to a low dose of ketoprofen at 4 and 6 post-operative hours. The TOTPAR scores were better for the ibuprofen when compared to meclofenamate at 8 post-surgical hours (Table S3). The pooled analysis showed that ibuprofen decreases the number of patients using the rescue medication when compared to aceclofenac, aspirin, and bromfenac. However, ibuprofen was inferior to bromfenac (100 mg). The comparison between ibuprofen and diclofenac, metamizole, naproxen sodium, low doses of bromfenac, and ketoprofen showed no differences (Figure 3). The overall evaluation supports the previous outcomes of SPID, TOTPAR, and rescue analgesics taken meta-analysis (Figure 4). 


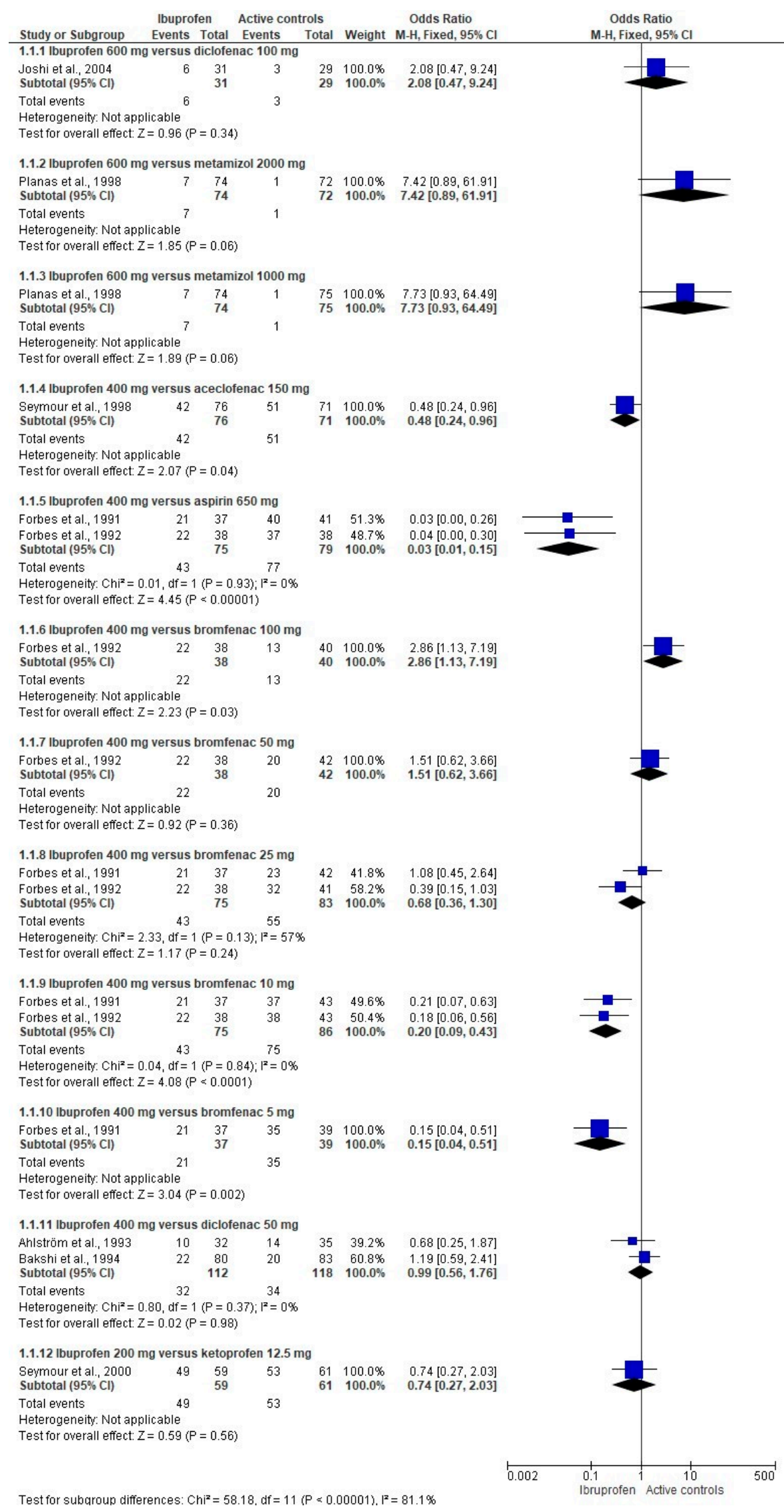

Figure 3. Meta-analysis of the number of patients using the rescue medication after third molar extraction. 


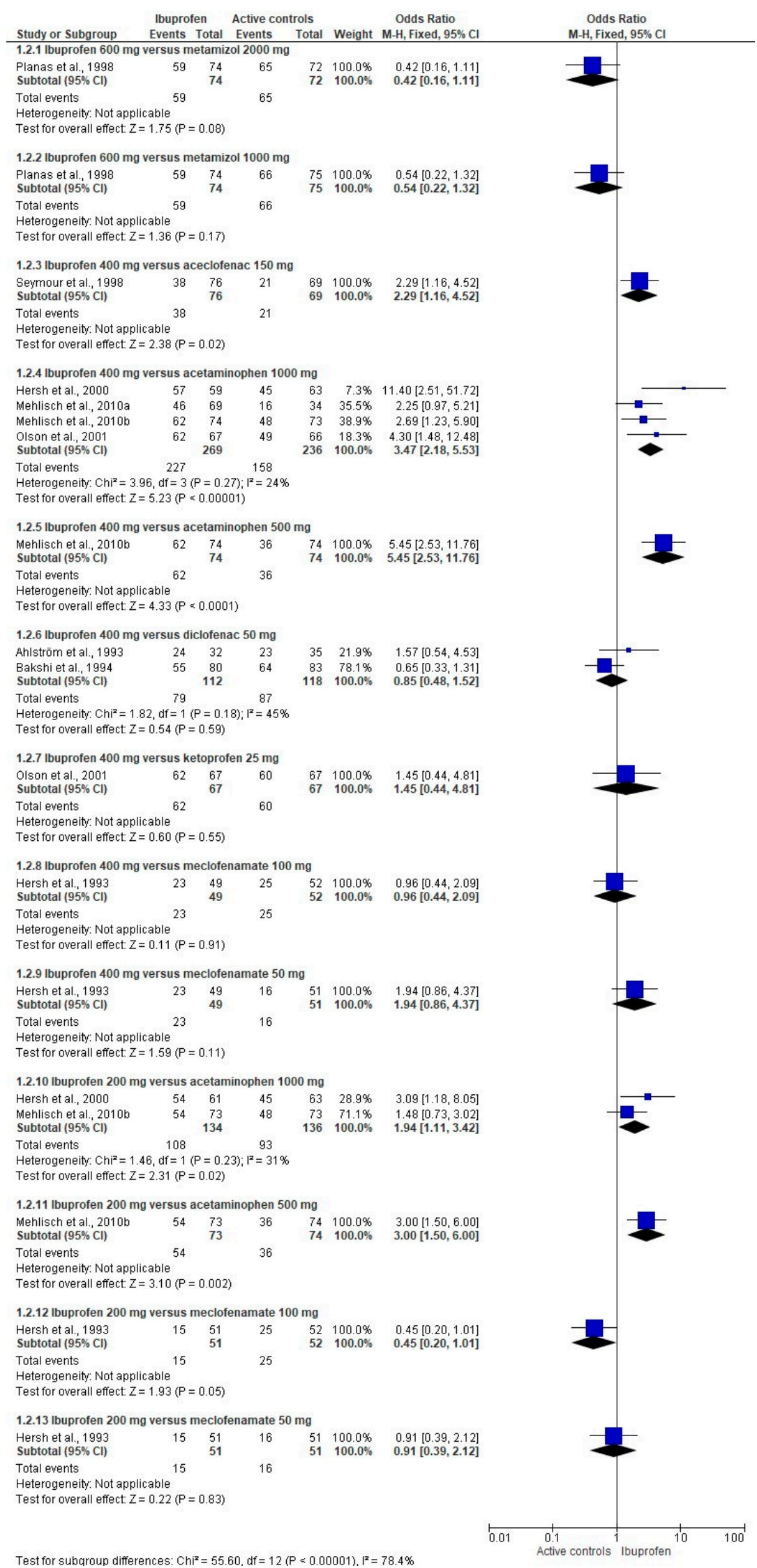

Figure 4. Combined analysis of the overall evaluation of the study medication following wisdom teeth surgery. 


\subsection{Adverse Effects}

The global assessment of adverse effects included 12 scientific reports $(n=2164)$. The result of this evaluation indicated that the adverse effects were similar between ibuprofen and other traditional NSAIDs [23-29,31,32,35-37] (Figure 5).

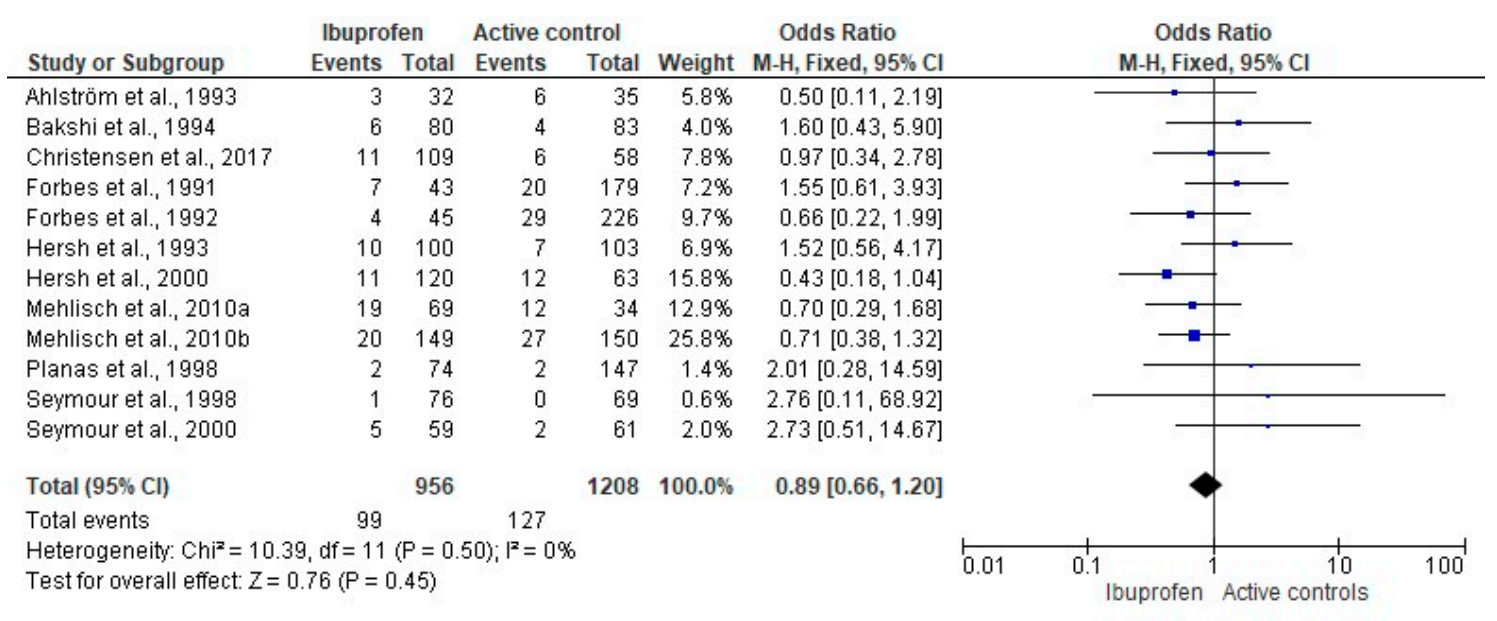

Figure 5. Pooled comparison of adverse effects after third molar surgery.

\section{Discussion}

The primary outcomes of this study showed that ibuprofen $400 \mathrm{mg}$ is more effective than acetaminophen $1000 \mathrm{mg}$ to relieve pain following third molar extraction. Likewise, ibuprofen $200 \mathrm{mg}$ was better than acetaminophen $1000 \mathrm{mg}$ for the management of post-operative pain following third molar removal. These findings are supported by a meta-analysis informing that ibuprofen 200 to $512 \mathrm{mg}$ is a better analgesic treatment than acetaminophen 600 to $1000 \mathrm{mg}$ in mandibular wisdom teeth removal [15]. That review included in the statistical analysis the data of the clinical trial by Mehlisch et al., 1995, which included a comparison between ibuprofen-lysine combination and acetaminophen [38]. That is, the individual effect of ibuprofen was not evaluated, but rather that of the combination of drugs versus acetaminophen. For this reason, this article by Mehlisch et al., 1995, was not included in our review.

In this same regard, ibuprofen has been shown to be a better analgesic than acetaminophen in different surgical fields. Thybo et al., 2019, demonstrated that an ibuprofen $400 \mathrm{mg}$ - acetaminophen $1000 \mathrm{mg}$ combination had a superior analgesic efficacy (reduction of the morphine post-operative intake) than acetaminophen $1000 \mathrm{mg}$ alone for pain control in total hip arthroplasty. However, the comparison of this drug combination was similarly effective to ibuprofen $400 \mathrm{mg}$ alone for the management of pain following total hip arthroplasty [39]. Kamondetdecha and Tannirandorn (2008) reported that ibuprofen $400 \mathrm{mg}$ offered a better analgesic effect than acetaminophen $1000 \mathrm{mg}$ after childbirth [40]. Ekinci et al., 2020, carried out a randomized, double-blind clinical trial to assess postoperative pain relief using ibuprofen $800 \mathrm{mg}$, acetaminophen $1000 \mathrm{mg}$, and placebo in laparoscopic cholecystectomy surgery. The authors observed that ibuprofen was better than acetaminophen [41]. Ciftci et al., 2019 found that an ibuprofen $800 \mathrm{mg}$ group showed low pain scores and minor rescue analgesic intake when compared to the acetaminophen $1000 \mathrm{mg}$ group after laparoscopic sleeve gastrectomy [42]. Erdogan-Kayhan et al., 2018, reported that ibuprofen $400 \mathrm{mg}$ reduced the pain intensity scores in comparison to acetaminophen $1000 \mathrm{mg}$ in bariatric surgery [43].

The pooled primary and secondary endpoints evaluation of the analgesic efficacy of ibuprofen $400 \mathrm{mg}$ and diclofenac $50 \mathrm{mg}$ showed no difference. However, the data trend was in favor of diclofenac. It would be important to increase the number of randomized double-blinding clinical trials using a dose of ibuprofen and diclofenac to obtain a definitive 
conclusion on the analgesic efficacy of these drugs in this kind of surgical procedure. In this same sense, a multiple-dose study showed no difference between these drugs after third molar surgery [44]. Moreover, Gazal and Al-Samadani (2017) demonstrated that ibuprofen had an inferior analgesic activity than diclofenac for dental removal and deep cavity preparation [45].

According to the secondary outcomes, ibuprofen $400 \mathrm{mg}$ reduces the number of patients requiring rescue analgesic medication in the post-operative period when compared to aspirin $650 \mathrm{mg}$, aceclofenac $150 \mathrm{mg}$, and bromfenac 5 and $10 \mathrm{mg}$. Nevertheless, Moore et al., 2015, demonstrated through an indirect comparison that ibuprofen $400 \mathrm{mg}$ is better than aspirin $1000 \mathrm{mg}$ for dental pain management [46].

In this review and meta-analysis, we observed a similar risk of adverse effects between ibuprofen and other NSAIDs following wisdom teeth surgery. This is consistent with the findings previously reported by various authors. Southey et al., 2009, and Tan et al., 2020, showed that ibuprofen and acetaminophen have similar safety profiles in pediatric patients [47,48]. van Walsem et al., 2015, found that the risk of fatal and nonfatal severe events was similar between diclofenac, acetaminophen, naproxen, ibuprofen, celecoxib, and etoricoxib. The authors observed a decreased risk of superior gastrointestinal adverse effects using diclofenac when compared with ibuprofen and naproxen in patients with osteoarthritis or rheumatoid arthritis [49]. It is worth noting that the clinical trials included in this review did not find fatal or severe adverse events.

Overall, this study was conducted using only high-quality randomized clinical trials employing rigorous methods [50-52]. The most important weakness was that ibuprofen was compared with many active treatments and different doses of these drugs, which made a combined data analysis impossible on many occasions [51,52]. Another disadvantage is that only single-dose studies were included. A multiple-dose scheme is more closely related to the real use of NSAIDs [53].

In conclusion, the synthesis of information and statistical analysis carried out here is intended to be a guide in the choice of one-dose analgesics in third molar surgery. Used under this scheme, ibuprofen $400 \mathrm{mg}$ appears to have good analgesic efficacy and a safety profile similar to other traditional NSAIDs after third molar surgery.

Supplementary Materials: The following are available online at https: / www.mdpi.com/article / 10.3390/ph14040360/s1, Table S1: Features summary of the high-quality studies. Table S2: Metaanalytical evaluation of the sum of pain intensity differences at 2 and 6 post-surgical hours. Table S3: Pooled assessment of the total pain relief at 2, 4, 6, and $8 \mathrm{~h}$ after surgery.

Author Contributions: M.A.I.-E.: conception and design of review, acquisition of data (literature search), analysis and interpretation of data collected, drafting of article and/or critical revision, and final approval and guarantor of manuscript. N.P.F.-F. and D.L.F.-G.: acquisition of data (literature search), analysis and interpretation of data collected, drafting of article and/or critical revision, and final approval and guarantor of manuscript. L.F.-d.1.T. and Á.J.A.-C.: acquisition of data (literature search), analysis and interpretation of data collected, drafting of article and/or critical revision, and final approval and guarantor of manuscript. F.R.-L.: critical revision and final approval and guarantor of manuscript. All authors have read and agreed to the published version of the manuscript.

Funding: This work was supported by the CUALTOS-UDG (grant number PROSNI 2020-Mario Alberto Isiordia-Espinoza).

Institutional Review Board Statement: Not applicable.

Informed Consent Statement: Not applicable.

Data Availability Statement: Data is contained within the article.

Acknowledgments: This manuscript was reviewed by a native English speaker.

Conflicts of Interest: The authors declare no conflict of interest. 


\section{References}

1. Osunde, O.D.; Adebola, R.A.; Omeje, U.K. Management of inflammatory complications in third molar surgery: A review of the literature. Afr. Health Sci. 2011, 11, 530-537. [PubMed]

2. Bouloux, G.F.; Steed, M.B.; Perciaccante, V.J. Complications of third molar surgery. Oral Maxillofac. Surg. Clin. N. Am. 2007, 19, 117-128. [CrossRef] [PubMed]

3. Carrasco-Labra, A.; Brignardello-Petersen, R.; Yanine, N.; Araya, I.; Guyatt, G. Secondary versus primary closure techniques for the prevention of postoperative complications following removal of impacted mandibular third molars: A systematic review and meta-analysis of randomized controlled trials. J. Oral Maxillofac. Surg. 2012, 70, e441-e457. [CrossRef]

4. Sainz de Baranda, B.; Silvestre, F.J.; Silvestre-Rangil, J. Relationship between surgical difficulty of third molar extraction under local anesthesia and the postoperative evolution of clinical and blood parameters. J. Oral Maxillofac. Surg. 2019, 77, $1337-1345$. [CrossRef] [PubMed]

5. Al-Delayme, R.M.A. Randomized clinical study comparing Piezoelectric surgery with conventional rotatory osteotomy in mandibular third molars surgeries. Saudi Dent. J. 2021, 33, 11-21. [CrossRef]

6. Hellem, S.; Persson, G.; Freiberg, N.; Nord, P.G.; Gustafsson, B.; Huitfeldt, B. A model for evaluating the analgesic effect of a new fixed ratio combination analgesic in patients undergoing oral surgery. Int. J. Oral Surg. 1979, 8, 435-442. [CrossRef]

7. Seymour, R.A.; Walton, J.G. Pain control after third molar surgery. Int. J. Oral Surg. 1984, 13, 457-485. [CrossRef]

8. Orozco-Solís, M.; García-Ávalos, Y.; Pichardo-Ramírez, C.; Tobías-Azúa, F.; Zapata-Morales, J.R.; Aragon-Martínez, O.H.; IsiordiaEspinoza, M.A. Single dose of diclofenac or meloxicam for control of pain, facial swelling, and trismus in oral surgery. Med. Oral Patol. Oral Cir. Bucal 2016, 21, e127-e134. [CrossRef] [PubMed]

9. Pérez-González, J.M.; Esparza-Villalpando, V.; Martínez-Rider, R.; Noyola-Frías, M.Á.; Pozos-Guillén, A. Clinical and radiographic characteristics as predictive factors of swelling and trismus after mandibular third molar surgery: A longitudinal approach. Pain Res. Manag. 2018, 7938492. [CrossRef]

10. Roszkowski, M.T.; Swift, J.Q.; Hargreaves, K.M. Effect of NSAID administration on tissue levels of immunoreactive prostaglandin E2, leukotriene B4, and (S)-flurbiprofen following extraction of impacted third molars. Pain 1997, 73, 339-345. [CrossRef]

11. Chopra, D.; Rehan, H.S.; Mehra, P.; Kakkar, A.K. A randomized, double-blind, placebo-controlled study comparing the efficacy and safety of paracetamol, serratiopeptidase, ibuprofen and betamethasone using the dental impaction pain model. Int. J. Oral Maxillofac. Surg. 2009, 38, 350-355. [CrossRef] [PubMed]

12. Schultze-Mosgau, S.; Schmelzeisen, R.; Frölich, J.C.; Schmele, H. Use of ibuprofen and methylprednisolone for the prevention of pain and swelling after removal of impacted third molars. J. Oral Maxillofac. Surg. 1995, 53, 2-7. [CrossRef]

13. Manvelian, G.; Daniels, S.; Gibofsky, A. A phase 2 study evaluating the efficacy and safety of a novel, proprietary, nano-formulated, lower dose oral diclofenac. Pain Med. 2012, 13, 1491-1498. [CrossRef] [PubMed]

14. Tuzuner Oncul, A.M.; Yazicioglu, D.; Alanoglu, Z.; Demiralp, S.; Ozturk, A.; Ucok, C. Postoperative analgesia in impacted third molar surgery: The role of preoperative diclofenac sodium, paracetamol and lornoxicam. Med. Princ. Pract. 2011, 20, 470-476. [CrossRef] [PubMed]

15. Bailey, E.; Worthington, H.V.; van Wijk, A.; Yates, J.M.; Coulthard, P.; Afzal, Z. Ibuprofen and/or paracetamol (acetaminophen) for pain relief after surgical removal of lower wisdom teeth. Cochr. Database Syst. Rev. 2013, CD004624. [CrossRef]

16. Higgins, J.P.; Green, S. (Eds.) Cochrane Handbook for Systematic Reviews of Interventions Version 5.1.0; The Cochrane Collaboration: Oxford, UK, 2011; Available online: http:/ / www.cochrane-handbook.org (accessed on 15 October 2020).

17. Jones, A.; Steel, D. Evaluating the quality of medical evidence in real-world contexts. J. Eval. Clin. Pract. 2018, 24, 950-956. [CrossRef] [PubMed]

18. Atkins, D.; Eccles, M.; Flottorp, S.; Guyatt, G.H.; Henry, D.; Hill, S.; Liberati, A.; O'Connell, D.; Oxman, A.D.; Phillips, B.; et al. Systems for grading the quality of evidence and the strength of recommendations I: Critical appraisal of existing approaches The GRADE Working Group. BMC Health Serv. Res. 2004, 4, 38. [CrossRef] [PubMed]

19. Isiordia-Espinoza, M.A.; Aragon-Martinez, O.H.; Bollogna-Molina, R.E.; Alonso-Castro, Á.J. Infection, alveolar osteitis, and adverse effects using metronidazole in healthy patients undergoing third molar surgery: A meta-analysis. J. Maxillofac. Oral Surg. 2018, 17, 142-149. [CrossRef]

20. Isiordia-Espinoza, M.A.; Aragon-Martinez, O.H.; Martínez-Morales, J.F.; Zapata-Morales, J.R. Risk of wound infection and safety profile of amoxicillin in healthy patients which required third molar surgery: A systematic review and meta-analysis. Br. J. Oral Maxillofac. Surg. 2015, 53, 796-804. [CrossRef]

21. Isiordia-Espinoza, M.A.; Pozos-Guillén, A.J.; Aragon-Martinez, O.H. Analgesic efficacy and safety of single-dose tramadol and non-steroidal anti-inflammatory drugs in operations on the third molars: A systematic review and meta-analysis. Br. J. Oral Maxillofac. Surg. 2014, 52, 775-783. [CrossRef]

22. Higgins, J.P.; Thompson, S.G.; Deeks, J.J.; Altman, D.G. Measuring inconsistency in meta-analyses. BMJ 2003, 327, 557-560. [CrossRef]

23. Ahlström, U.; Bakshi, R.; Nilsson, P.; Wåhlander, L. The analgesic efficacy of diclofenac dispersible and ibuprofen in postoperative pain after dental extraction. Eur. J. Clin. Pharmacol. 1993, 44, 587-588. [CrossRef]

24. Bakshi, R.; Frenkel, G.; Dietlein, G.; Meurer-Witt, B.; Schneider, B.; Sinterhauf, U. A placebo-controlled comparative evaluation of diclofenac dispersible versus ibuprofen in postoperative pain after third molar surgery. J. Clin. Pharmacol. 1994, 34, 225-230. [CrossRef] 
25. Christensen, S.; Paluch, E.; Jayawardena, S.; Daniels, S.; Meeves, S. Analgesic efficacy of a new immediate-release/extendedrelease formulation of ibuprofen: Results from single- and multiple-dose postsurgical dental pain studies. Clin. Pharmacol. Drug. Dev. 2017, 6, 302-312. [CrossRef]

26. Forbes, J.A.; Edquist, I.A.; Smith, F.G.; Schwartz, M.K.; Beaver, W.T. Evaluation of bromfenac, aspirin, and ibuprofen in postoperative oral surgery pain. Pharmacotherapy 1991, 11, 64-70. [PubMed]

27. Forbes, J.A.; Beaver, W.T.; Jones, K.F.; Edquist, I.A.; Gongloff, C.M.; Smith, W.K.; Smith, F.G.; Schwartz, M.K. Analgesic efficacy of bromfenac, ibuprofen, and aspirin in postoperative oral surgery pain. Clin. Pharmacol. Ther. 1992, 51, 343-352. [CrossRef] [PubMed]

28. Hersh, E.V.; Cooper, S.; Betts, N.; Wedell, D.; MacAfee, K.; Quinn, P.; Lamp, C.; Gaston, G.; Bergman, S.; Henry, E. Single dose and multidose analgesic study of ibuprofen and meclofenamate sodium after third molar surgery. Oral Surg. Oral Med. Oral Pathol. 1993, 76, 680-687. [CrossRef]

29. Hersh, E.V.; Levin, L.M.; Cooper, S.A.; Doyle, G.; Waksman, J.; Wedell, D.; Hong, D.; Secreto, S.A. Ibuprofen liquigel for oral surgery pain. Clin. Ther. 2000, 22, 1306-1318. [CrossRef]

30. Joshi, A.; Parara, E.; Macfarlane, T.V. A double-blind randomised controlled clinical trial of the effect of preoperative ibuprofen, diclofenac, paracetamol with codeine and placebo tablets for relief of postoperative pain after removal of impacted third molars. Br. J. Oral Maxillofac. Surg. 2004, 42, 299-306. [CrossRef] [PubMed]

31. Mehlisch, D.R.; Aspley, S.; Daniels, S.E.; Bandy, D.P. Comparison of the analgesic efficacy of concurrent ibuprofen and paracetamol with ibuprofen or paracetamol alone in the management of moderate to severe acute postoperative dental pain in adolescents and adults: A randomized, double-blind, placebo-controlled, parallel-group, single-dose, two-center, modified factorial study. Clin. Ther. 2010, 32, 882-895. [PubMed]

32. Mehlisch, D.R.; Aspley, S.; Daniels, S.E.; Southerden, K.A.; Christensen, K.S. A single-tablet fixed-dose combination of racemic ibuprofen/paracetamol in the management of moderate to severe postoperative dental pain in adult and adolescent patients: A multicenter, two-stage, randomized, double-blind, parallel-group, placebo-controlled, factorial study. Clin. Ther. 2010, 32, 1033-1049. [PubMed]

33. Morrison, B.W.; Fricke, J.; Brown, J.; Yuan, W.; Kotey, P.; Mehlisch, D. The optimal analgesic dose of rofecoxib: Overview of six randomized controlled trials. J. Am. Dent. Assoc. 2000, 131, 1729-1737. [CrossRef] [PubMed]

34. Olson, N.Z.; Otero, A.M.; Marrero, I.; Tirado, S.; Cooper, S.; Doyle, G.; Jayawardena, S.; Sunshine, A. Onset of analgesia for liquigel ibuprofen $400 \mathrm{mg}$, acetaminophen $1000 \mathrm{mg}$, ketoprofen $25 \mathrm{mg}$, and placebo in the treatment of postoperative dental pain. J. Clin. Pharmacol. 2001, 41, 1238-1247. [CrossRef]

35. Planas, M.E.; Gay-Escoda, C.; Bagán, J.V.; Santamaría, J.; Peñarrocha, M.; Donado, M.; Puerta, J.L.; García-Magaz, I.; Ruíz., J.; Ortiz, P. Oral metamizol ( $1 \mathrm{~g}$ and $2 \mathrm{~g}$ ) versus ibuprofen and placebo in the treatment of lower third molar surgery pain: Randomised double-blind multi-centre study. Cooperative Study Group. Eur. J. Clin. Pharmacol. 1998, 53, 405-409. [CrossRef] [PubMed]

36. Seymour, R.A.; Frame, J.; Negus, T.W.; Hawkesford, J.E.; Marsden, J.; Matthew, I.R. The comparative efficacy of aceclofenac and ibuprofen in postoperative pain after third molar surgery. Br. J. Oral Maxillofac. Surg. 1998, 36, 375-379. [CrossRef]

37. Seymour, R.A.; Watkinson, H.; Hawkesford, J.E.; Moore, U. The efficacy of buffered ketoprofen in postoperative pain after third molar surgery. Eur. J. Clin. Pharmacol. 2000, 55, 801-806. [CrossRef] [PubMed]

38. Mehlisch, D.R.; Jasper, R.D.; Brown, P.; Korn, S.H.; McCarroll, K.; Murakami, A.A. Comparative study of ibuprofen lysine and acetaminophen in patients with postoperative dental pain. Clin. Ther. 1995, 17, 852-860. [CrossRef]

39. Thybo, K.H.; Hägi-Pedersen, D.; Dahl, J.B.; Wetterslev, J.; Nersesjan, M.; Jakobsen, J.C.; Pedersen, N.A.; Overgaard, S.; Schrøder H.M.; Schmidt, H.; et al. Effect of combination of paracetamol (acetaminophen) and ibuprofen vs either alone on patient-controlled morphine consumption in the first 24 hours after total hip arthroplasty: The PANSAID randomized clinical trial. JAMA 2019, 321, 562-571. [CrossRef]

40. Kamondetdecha, R.; Tannirandorn, Y. Ibuprofen versus acetaminophen for the relief of perineal pain after childbirth: A randomized controlled trial. J. Med. Assoc. Thail. 2008, 91, 282-286. [CrossRef]

41. Ekinci, M.; Ciftci, B.; Celik, E.C.; Köse, E.A.; Karakaya, M.A.; Ozdenkaya, Y. A randomized, placebo-controlled, double-blind study that evaluates efficacy of intravenous ibuprofen and acetaminophen for postoperative pain treatment following laparoscopic cholecystectomy surgery. J. Gastrointest. Surg. 2020, 24, 780-785. [CrossRef]

42. Ciftci, B.; Ekinci, M.; Celik, E.C.; Kaciroglu, A.; Karakaya, M.A.; Demiraran, Y.; Ozdenkaya, Y. Comparison of intravenous ibuprofen and paracetamol for postoperative pain management after laparoscopic sleeve gastrectomy. A randomized controlled study. Obes. Surg. 2019, 29, 765-770. [CrossRef]

43. Erdogan-Kayhan, G.; Sanli, M.; Ozgul, U.; Kirteke, R.; Yologlu, S. Comparison of intravenous ibuprofen and acetaminophen for postoperative multimodal pain management in bariatric surgery: A randomized controlled trial. J. Clin. Anesth. 2018, 50, 5-11. [CrossRef]

44. Esteller-Martínez, V.; Paredes-García, J.; Valmaseda-Castellón, E.; Berini-Aytés, L.; Gay-Escoda, C. Analgesic efficacy of diclofenac sodium versus ibuprofen following surgical extraction of impacted lower third molars. Med. Oral Patol. Oral Cir. Bucal 2004, 9 , 448-453. [PubMed]

45. Gazal, G.; Al-Samadani, K.H. Comparison of paracetamol, ibuprofen, and diclofenac potassium for pain relief following dental extractions and deep cavity preparations. Saudi Med. J. 2017, 38, 284-291. [CrossRef] [PubMed] 
46. Moore, R.A.; Derry, S.; Aldington, D.; Wiffen, P.J. Single dose oral analgesics for acute postoperative pain in adults-an overview of Cochrane reviews. Cochrane Database Syst. Rev. 2015, 2015, CD008659. [CrossRef]

47. Southey, E.R.; Soares-Weiser, K.; Kleijnen, J. Systematic review and meta-analysis of the clinical safety and tolerability of ibuprofen compared with paracetamol in paediatric pain and fever. Curr. Med. Res. Opin. 2009, 25, 2207-2222. [CrossRef]

48. Tan, E.; Braithwaite, I.; McKinlay, C.J.D.; Dalziel, S.R. Comparison of acetaminophen (paracetamol) with ibuprofen for treatment of fever or pain in children younger than 2 years: A systematic review and meta-analysis. JAMA Netw. Open 2020, 3, e2022398. [CrossRef]

49. van Walsem, A.; Pandhi, S.; Nixon, R.M.; Guyot, P.; Karabis, A.; Moore, R.A. Relative benefit-risk comparing diclofenac to other traditional non-steroidal anti-inflammatory drugs and cyclooxygenase-2 inhibitors in patients with osteoarthritis or rheumatoid arthritis: A network meta-analysis. Arthritis Res. Ther. 2015, 17, 66. [CrossRef] [PubMed]

50. Panic, N.; Leoncini, E.; de Belvis, G.; Ricciardi, W.; Boccia, S. Evaluation of the endorsement of the preferred reporting items for systematic reviews and meta-analysis (PRISMA) statement on the quality of published systematic review and meta-analyses. PLoS ONE 2013, 8, e83138. [CrossRef]

51. Argimon-Pallás, J.M.; Jiménez-Villa, J. Métodos de Investigación Clínica y Epidemiológica, 5th ed.; Elsevier: Barcelona, Spain, 2019.

52. Dawson, B.; Trapp, R.G. Bioestadística Médica, 4th ed.; Editorial El Manual Moderno: Mexico City, Mexico, 2005.

53. Akinbade, A.O.; Ndukwe, K.C.; Owotade, F.J. Comparative analgesic effects of ibuprofen, celecoxib and tramadol after third molar surgery: A randomized double blind controlled trial. J. Contemp. Dent. Pract. 2018, 19, 1334-1340. [CrossRef] 